- sustainable manner despite the challenges. "We realize that there are huge issues when working in the cold and darkness and in the presence of sea ice in areas at great distance from any infrastructure," says Joseph Mullin, a London-based programme manager at the International Association of Oil and Gas Producers. Mullin will oversee a four-year, US\$20-million research programme to address those issues, launched at the Tromsø conference by nine major oil companies.

The initiative, which is open to academic collaborators, will include research on the environmental effects of Arctic oil spills, spill trajectory modelling and remote sensing, and oil recovery techniques in sea-ice areas. It will also test Arctic clean-up technologies in a number of controlled oil releases. "You'd like to have a variety of spill-response options in the tool box before you venture out there," says Mullin.

The leading Russian oil and gas companies,
RUSSIA

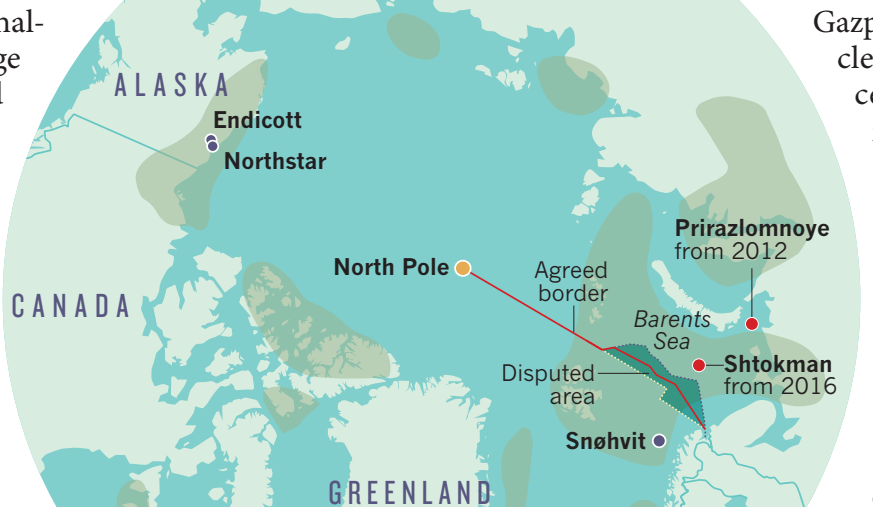

Gazprom and Rosneft, have so far stayed clear of the initiative, adding to concerns about their compliance with national and international safety standards.

In December 2011, for example, at least 37 people were killed when an oil rig under contract to Gazprom capsized off Sakhalin Island in Russia's Arctic Ocean, resulting in a fine for the company.

And according to Vladimir Chuprov, a Moscow-based energy expert who works for Greenpeace, emergency contingency plans for the Prirazlomnoye oil platform in the Russian Barents Sea, where commercial drilling is to start this year, have not been publicly released, despite being required by Russian regulators.

But even companies with better safety records should avoid the Arctic, say Chuprov and other environmentalists. "In our view no company is ready for offshore oil projects in the Arctic Ocean," he says.

PSYCHIATRY

\title{
Diagnostics tome comes under fire
}

\section{Field tests of new criteria are flawed, critics argue.}

\section{BY HEIDI LEDFORD}

$\mathrm{D}$ iagnoses of certain mental illnesses could rise significantly from next year, say some mental-health experts - but not because of any real changes in prevalence. Instead, the critics blame what they say is a flawed approach to testing the latest version of the Diagnostic and Statistical Manual of Mental Disorders (DSM), the standard reference used by researchers and mental-health professionals in the United States and many other countries to assess patients, inform treatment, design studies and guide health insurers.

Changes to the diagnostic criteria in the fifth edition of the manual, DSM-5, due to be published in May 2013 by the American Psychiatric Association (APA) in Arlington, Virginia, have raised concerns that some disorders will be overdiagnosed (see table). Critics say that the analysis of field tests of the new criteria won't settle those concerns.

Trials of DSM-5 conducted at 11 academic centres were completed last October. In a
Commentary published in the American Journal of Psychiatry (H. C. Kraemer et al. Am. J. Psychiatry 169, 13-15; 2012), members of the task force explained that the aim was not to focus on the frequency of a given diagnosis under the proposed DSM-5 criteria compared with that under the previous criteria. Because there is no accepted prevalence for most psychiatric disorders, they argued, it would be impossible to tell whether a rise in diagnoses reflects a true increase in the sensitivity of the revised criteria or simply a rise in the number of false positives.

That raised the hackles of some researchers, who say that without such comparisons it will be impossible to flag up the possibility that some categories will show an increased prevalence. "It's a real step back," says Thomas Widiger, a psychologist at the University of Kentucky in Lexington, who notes that trials of DSM-IV were careful to compare old and new diagnostic criteria to see which performed better.

Allen Frances, emeritus professor of psychiatry at Duke University in Durham, North Carolina, led the 1994 DSM-IV revision and is an outspoken critic of DSM-5. Frances

\section{CONTENTIOUS PROPOSALS FOR DSM-5}

Changes to diagnoses of some mental illnesses are causing disquiet about the consequences for patients.

\begin{tabular}{l|l|} 
Disorder & Change \\
$\begin{array}{l}\text { Autism spectrum } \\
\text { disorder }\end{array}$ & $\begin{array}{l}\text { Combines multiple DSM-IV diagnoses into one; } \\
\text { changes number of criteria needed for diagnosis }\end{array}$ \\
$\begin{array}{l}\text { Attenuated } \\
\text { psychosis syndrome }\end{array}$ & New diagnosis \\
$\begin{array}{l}\text { Major depressive } \\
\text { episode }\end{array}$ & Removes "bereavement" exclusion \\
$\begin{array}{l}\text { Mild neurocognitive } \\
\text { disorder }\end{array}$ & New diagnosis \\
\hline
\end{tabular}

Reason for controversy

Concerns about underdiagnosis, loss of eligibility for state support

Concerns about overdiagnosis/ overmedication

Concerns about overdiagnosis/ overmedication

Concerns about overdiagnosis/ overmedication 
acknowledges that the field trials for DSM-IV were far from perfect. For example, his trials failed to identify the dramatic surge in diagnoses of attention-deficit/hyperactivity disorder that followed changes made in DSM-IV. The trials suggested that there would be an increase of about $15 \%$ in the disorder. Instead, says Frances, the diagnosis rose threefold. "We missed the boat," he says. "But at least we had some sense that there would be an increase."

Results from the DSM-5 academic field trials have yet to be presented, but early calculations suggest that, in general, there will be no big differences in the frequency of diagnoses, says Darrel Regier, vice-chair of the DSM-5 task force and APA director of research. That claim has done little to alleviate concerns, however, because the trials enrolled patients who were initially diagnosed under DSM-IV standards. This leaves untested the possibility that the DSM-5 criteria will capture many more patients who were previously deemed healthy, notes Widiger.

Observers are also alarmed by the statistical thresholds that the trials used to assess reliability, or the likelihood that two or more clinicians would arrive at the same diagnosis using the proposed criteria. This likelihood is often expressed as a statistical term called 'Cohen's kappa'. A kappa of 0 means that there is no agreement between the clinicians; a value of 1 means that the clinicians agree totally.

Researchers in the field often strive to reach a kappa of $0.6-0.8$, indicating that the independent diagnoses agree more often than not. But in the Commentary, lead author Helena Kraemer, an emeritus statistician at Stanford School of Medicine in California, argued that a kappa of $0.2-0.4$ could sometimes be acceptable. Kraemer later elaborated to Nature that the task force was largely aiming for a kappa of 0.4-0.6, but that it wanted to prepare the field for seeing values as low as 0.2 in particularly rare diagnoses or in those without biological markers.

Unlike tests on the previous edition, the reliability tests on DSM-5 were performed on separate occasions, so that the clinicians involved were unaware of each other's diagnoses. Widiger says that he supports the more rigorous approach, but that accepting a value as low as 0.2 gives him pause. "I've never seen anybody argue that a kappa of 0.2 is acceptable," he says. "You just can't get much lower than that."

Not everyone is worried about a surge in diagnoses. Thomas Frazier, a paediatric psychologist at the Cleveland Clinic in Ohio, has carried out his own study of DSM-5 criteria for autism spectrum disorder. His results, published online last year (T. W. Frazier et al. J. Am. Acad. Child Adolesc. Psychiatry 51, 28-40; 2012), suggested that the new definition would omit some patients with autism, but that this could be easily corrected by requiring one less symptom to meet the threshold for a positive diagnosis. "Unfortunately, the DSM committees are not systematically doing these kinds of studies," he says. -
FUNDING

Stem-cell agency
faces budget dilemma

The California Institute for Regenerative Medicine plans for a future without state support.

\section{BY ERIKA CHECK HAYDEN}

$\mathrm{H}$ alfway through its initial ten-year mandate, the California Institute for Regenerative Medicine (CIRM) in San Francisco is confronting a topic familiar to anyone at middle age: its own mortality.

The publicly funded institute, one of the world's largest supporters of stem-cell research, was born from a state referendum in 2004. Endorsements from celebrities such as then-state governor Arnold Schwarzenegger and the late actor Christopher Reeve, who had been paralysed by a spinal injury, helped to garner voter support for a public bond to underwrite the institute. But with half of the US $\$ 3$ billion that it received from the state now spent and the rest expected to run out by 2021, CIRM is now actively planning for a future that may not include any further state support.

"It would be premature to even consider another bond measure at this time," wrote Jonathan Thomas, CIRM's chairman, in a draft of a transition plan requested by the state legislature. Thomas outlined the plan on 24 January at a public hearing held in San Francisco by the US Institute of Medicine, which CIRM has asked to review its operations.

Given that California is facing severe budget shortfalls, several billion dollars more for stem-cell science may strike residents as a luxury that they can ill afford. It may also prove difficult for CIRM's supporters to point to any treatments that have emerged from the state's investment. So far, the agency has funded only one clinical trial using embryonic stem cells, and that was halted by its sponsor, Geron of Menlo Park, California, last November.

Yet the institute has spent just over $\$ 1$ billion on new buildings and labs, basic research, training and translational research, often for projects that scientists say are crucial and would be difficult to get funded any other way. So the prospect of a future without CIRM is provoking unease. "It would be a very different landscape if CIRM were not $\rightarrow$ NATURE.COM Read more about CIRM's history and impact:

go.nature.com/hpedms

around," says Howard Chang, a dermatologist and genome scientist at Stanford University in California.

Chang has a CIRM grant to examine epigenetics in human embryonic stem cells, and is part of another CIRM-funded team that is preparing a developmental regulatory protein for use as a regenerative therapy. Both projects would be difficult to continue without the agency, he says. Federal funding for research using human embryonic stem cells remains controversial, and could dry up altogether after the next presidential election (see Nature 481, 421$423 ; 2012$ ). And neither of Chang's other funders - the US

"It would be a very different landscape if CIRM were not around."

National Institutes of Health (NIH) and the Howard Hughes Medical Institute in Chevy Chase, Maryland - supports his interdisciplinary

translational work. Irina Conboy, a stemcell engineer at the University of California, Berkeley, who draws half of her lab's funding from CIRM, agrees that in supporting work that has specific clinical goals, the agency occupies a niche that will not easily be filled by basic-research funders. "The NIH might say that the work does not have a strong theoretical component, so you're not learning anything new," she says.

CIRM is developing plans to help its grantees to continue their work if the agency closes. One option is a non-profit 'venture philanthropy' fund that would raise money from private sources to support stem-cell research. The agency is also writing a strategic plan for the rest of its ten-year mandate that focuses on translating research into the clinic, acknowledging that CIRM's best shot at survival - and at sustaining future funding for stem-cell researchers - could come from a clinical success.

As CIRM board member Claire Pomeroy, chief executive of the University of California, Davis, Health System in Sacramento, noted at the agency's board meeting on 17 January: "If you asked the public what they would define as success, they would say a patient benefited." 